\title{
Anti-obesity and Hypolipidemic Effects of Morus alba- A Review
}

\author{
Hanaa S. Kadhum ${ }^{1}$, Mahdi M.Thuwaini² \\ ${ }^{1}$ Ass. Professor of Physiology, Dept. Laboratory Investigation, College of Science, Basra University, ${ }^{2}$ Professor \\ of Pathology, Dept. of Pathological Analysis, College of Medical and Healthy Techniques/ Southern Technique \\ University
}

\begin{abstract}
The prevalence of obesity was worldwide increase in the last 60 years. Obesity represented one of the public healthproblems, it markedly increased the incidence of many diseases:fatty liver,type 2 diabetes, hypertension, ischemic heart diseases, sleep apnea, osteoporosis, dementia, tumors and many other disorders.Recent reviews showed that many medicinal plants possesses anti-obesity effect.In the current review, PubMed, Web Science, Science Direct, Researchgate, Academia.edu and Scopus were searched to verify thehypolipidemic and anti-obesity activities of Morusalba.
\end{abstract}

Key words: Anti-obesity, overweight, hypolipidemia, Morus alba, Review

\section{Introduction}

The prevalence of obesity was worldwide increase in the last 60 years. Obesity represented one of the public health problems, it markedly increases the incidence of many diseases: fatty liver, type 2 diabetes, hypertension, ischemic heart diseases, sleep apnea, osteoporosis, dementia, tumors and many other disorders. Therefore, it deteriorated the quality of life. Behavioral interventions and lifestyle changes aimed toincrease energy expenditure andreduce the caloric intake showed limited efficacy because of complex etiology (hormonal, metabolic, and neurochemical). Many drugs were also used to suppress their appetite and avoid overeating ${ }^{(1)}$.In the current review, PubMed, Web Science, Science Direct, Researchgate, Academia.edu and Scopus were searched to verify thehypolipidemic and anti-obesity activities of Morusalba.

\section{Morusalba}

Morus alba (Family: Moraceae) fruits were used traditionally as anthelmintic, antibacterial, sedative, analgesic, antirheumatic, diuretic, hypotensive, hypoglycemic, purgative, restorative, tonic, and hypolipidemia $^{(2-6)}$. The phytochemical analysis showed that the plant contained tannins, steroids, phytosterols, sitosterols, glycosides, alkaloids, carbohydrates, proteins and aminoacids, flavanoids, phenolics, anthocyanins, anthroquinones, saponins, triterpenes, and glycosides ${ }^{(7-10)}$. The fruits contained protein $1.55 \mathrm{~g}$, lipids $0.48 \mathrm{~g}$, crude fiber $1.47 \mathrm{~g}$; and total carbohydrates $14.21 \mathrm{~g} / 100 \mathrm{~g}$ dry weight. The Total sugar content was $7.55 \mathrm{~g}$, ascorbic acid $15.2 \mathrm{mg}$, riboflavin $0.088 \mathrm{mg}$, niacin $3.10 \mathrm{mg} / 100 \mathrm{~g}$ fresh weight. The total phenolic contents was 7.7 to $11.2 \mathrm{mg} \mathrm{GAE} / \mathrm{g}$, and total flavonols 0.07 to $0.51 \mathrm{mg} / \mathrm{g}$ dry weight ${ }^{(11)}$. The elements and minerals detected in the fruits were: N 1.62-2.13, P 0.24-0.31, K 1.62-2.13, Ca 0.19-0.37, $\mathrm{Na} 0.01, \mathrm{Mg} 0.12-0.19$, S 0.08-0.11g/100 g. While, the fruits contained $\mathrm{Fe} 28.2-46.74, \mathrm{Cu}$ 4.22-6.38, B 13.78-19.48, Mn 12.33-19.38, Zn 14.89-19.58 and Ni $1.40-2.62 \mathrm{mg} / \mathrm{kg}^{(12)}$.

The freeze-dried powder of mulberry fruits contained phenols $23.0 \mathrm{mg} / \mathrm{g}$ GAE, flavonoids 3.9 
$\mathrm{mg} / \mathrm{g}$ rutin equivalents and anthocyanins $0.87 \mathrm{mg} / \mathrm{g}$ cyanidin-3-glucoside equivalents.Rutin $(0.43 \mathrm{mg} / \mathrm{g})$, morin $(0.16 \mathrm{mg} / \mathrm{g})$, quercetin $(0.01 \mathrm{mg} / \mathrm{g})$ and myricetin $(0.01 \mathrm{mg} / \mathrm{g})$ represented the main flavonol in the fruit powder ${ }^{(13)}$.

However, anthocyanins content of the fruit ethanol extract was 137 to $2057 \mathrm{mg}$ malvidin-3glucoside equivalents $/ \mathrm{kg}^{(14)}$. Anthocyanins isolated from the fruits included cyanidin 3- glucoside, cyanidin 3-O- $\beta$-D-glucopyranoside, cyanidin 3rutinoside, cyanidin 3-O-(6-O- $\alpha$-rhamnopyranosyl$\beta$-D-glucopyranoside), cyanidin 3-O-( 6- $O-\alpha$ rhamnopyranosyl- $\beta$ - D- galactopyranoside), cyanidin $3-O-\beta$-D-galactopyranoside and cyanidin $7-O-\beta$-Dglucopyranoside ${ }^{(15-16)}$.

Flavonoids identified in the fruits were astragalin, nicotiflorin, quercetin, isoquercitrin, morkotin $\mathrm{A}$ and $\mathrm{C}$, rutin, kaempferol 3-O- (6- O- malonyl) glucoside, kaempferol 3,7-di-O-glucoside, quercetin 3, 7di- O- glucoside andquercetin 3-O-(6-O-malonyl) glucoside ${ }^{(17)}$.The total phenolic contents ofMorus alba leaves were 2.64 to $7.33 \mathrm{mg}$ GAE/g dry weight and total flavonoids wer 0.95 to $2.39 \mathrm{mg} \mathrm{QE} / \mathrm{g}$ dry weight. The polyphenols isolated from the fruits and leaves of Morus albawere: gallic acid, caffeic acid, chlorogenic acid, $m$-coumaric acid, $p$-coumaric acid, ferulic acid, vanillic acid, $p$-hydroxybenzoic acid, protocatechuic acid,syringic acid, protocatechuic aldehyde, syringealdehyde, kaempferol, epicatechin, and rutin ${ }^{(18-19)}$.

The previous pharmacological researchesshowed that Morus albaexerted protective, neural, antiinflammatory, antimicrobial, analgesic, antipyretic, musculo-skeletal, immunological, antioxidant, antidiabetic, anticancer, cardiovascular, dermatological, gastrointestinal and respiratory the rapeutic effects.

\section{Hypolipidemic and anti-obesity effects:}

The antioxidant andhypolipidemicactivities of the root bark fractions of Morus alba were studied in rats fed high cholesterol diet. The results revealed that the administration of (50\% methanol and 100\% methanol) fractions ameliorated atherosclerotic state. Administration of $100 \%$ methanol fractionmarkedly restored the liver and plasma peroxides to normal limits, and significantly increased the resistance to at herogenic changes $(44,33$, and $30 \%$ reduction in the LDL oxidation, LDL retention and LDL aggregation, respectively). Mulberroside A, albanols $\mathrm{A}$ and $\mathrm{B}$ and 5,7,2'-trihydroxyflavanone-4'-O-beta-D-glucoside were identified in the rootr and bark fractions ${ }^{(20)}$.

Mulberry leaves extractcaused markeddecline in the triglycerides,LDL cholesterol and total cholesterol, and increased the serum level of HDL cholesterol in rats and mice (21-25). $^{2}$.

The aqueous extract of Mulberry leaves at a dose of $150 \mathrm{mg} / \mathrm{kg} / \mathrm{day}$, for 14 days, significantly decreased the triglycerides level by $55.01 \%$ in rats on high cholesterol diet ${ }^{(26)}$.

Morus alba leaves ethanol extractmarkedly decreased body weight gain, and diminished the elevated cholesterol, triglycerides, atherogenic index and coronary artery indices, it alsodecreased insulin resistance and glucose level in hyperlidemicrats induced by high- cholesterol diet (HCD). The serum leptin and resistinand their mRNA expression in visceral adipose tissue were significantly decreased by the extract, while, it increased serum adiponectin, and its expression significantly in visceral adipose tissue in hyperlipidemicrats ${ }^{(27)}$.

MulberrosideA (MUL), the pure root ethanolic extract of Mulberry, and oxyresveratrol (OXY), prepared from MUL enzymatically, were studied $(1-5 \mathrm{mg} / \mathrm{kg} / \mathrm{day}$, for 4weeks) for their hypolipidemic effect in high cholesterol diet (HCD)- 
induced hyperlipidemic, in triton WR-1339-induced hyperlipidemic rats, and normal rats. Tritoninduced hyperlipidemic ratspretreated with MUL and OXY orally, showed decreased levels of serum lipidssignificantly. MUL and OXY in HCD-fed rats caused significant decline in lipids andatherogenic index. In addition, MUL and OXY induced significant amelioratedthe histological hepatic changesin HCDhyperlipidemic rats. Liver enzymes values were not significantly different in OXY-treated normal rats compared to water-treated rats ${ }^{(28)}$.

The accumulation oflipid in the liver was decreased by Morus alba leaves extract, the number and the sizeof lipid droplets in hepatocytes were significantlyless than that in the control ${ }^{(22,24)}$.

Flavonoids, phenolics and 1-deoxynojirimycin, isolated from the leaves of mulberry decreased plasma lipids by many mechanisms as detected by in vitvoand in vitro experiments. Kaempferol, quercetin, and 1-deoxynojirimycin enrichedleaves extracts activated the expressions of AMP-activated protein kinase and PPAR-a, and increased lipid breakdown and free fatty acid $\beta$-oxidation ${ }^{(23,29)}$.

The leaves extract rich in polyphenol (quercetin, hydroxyflavin and caffeic acid)reducedlipogenesis by regulating of glycerol-3-phosphate acyltransferase, fatty acid synthase, liver $\mathrm{X}$ receptor and sterol regulatory element-binding proteins-1c ${ }^{(24,30-31)}$.

Moracin isolated from the leaves of Morus alba inhibited lipid peroxidation which strongly indicated its role as scavenger ${ }^{(26)}$.

The antioxidants and hypolipidemic effects of the fruits ofMorus alba were studied in hypercholestrolemic rats. The fruits of Morus alba at doses of $2.5,5$ and $10 \%$ caused significant increase in the antioxidant activity and significant decrease the total cholesterol, triglycerides, VLDL, and LDL cholesterol, with significant elevation in HDL cholesterol. ${ }^{(32)}$.

The effects of mulberry leaves extract fermentedby Cordycepsmilitaris for 12 weeks, on the lipolytic activity, metabolism and accumulation of the lipids were measured in obesity induced in mice by high fat diet (HFD). The levels of total cholesterol, triglyceride, LDL cholesterol, and glucose were significantly decreased, and the level of HDL-cholesterol was significantly increased in high fat diet (HFD) + extract treated group compared with the HFD group treated with vehicle. The the size of adipocytes and the amount of abdominal fat were significantly decreased. The mRNA levels of (PPAR $\gamma$ )for adipogenesisin addition,Fas cell surface death receptor and adipocyte protein 2 were decreased after12 weeks treatmentwith the extract ${ }^{(33)}$.

The effect of Ob-X, (contained: Artemisia capillaries, Morus alba andMelissa officinalis) on angiogenesis was determinedby miceMatrigel plug assay. Ob-X decreasedthe angiogenesis dosedependently. Ob-X for 5 weeks in mice caused $27 \%$ reduction in bodyweight gain. Furthermore, The visceral adipose tissue and the size of adipocytes in visceral adipose were decreased by 46 and $15 \%$, respectively. In addition, the treatmentalso significantly decreased the hepatic accumulation of lipids and the blood glucose levels ${ }^{(34)}$.

The effect of leaves extract on oxidative stress induced by obesity, in addition to its effect on lipogenesis, hepatic fibrosis, was investigated in obese mice fed high-fat diet (HFD). The extract significantly decreased LXR $\alpha$-mediated lipogenesis and hepatic fibrosis markers and up-regulated lipolysis-associated markers. Moreover, the extract restoredthe antioxidant enzymes activities in the HFD-fed mice ${ }^{(35)}$.

The benefit of synergismbetween $\beta$-glucan and the leaf extract of mulberry on metabolic health were studied inmice fed high fat diet. $\beta$-glucanadministration 
significantlydecreasedlipid profile, fat mass, fatty liver, body weight gain, insulin, and inflammatory markers. On the other hand, the administration of mulberry leaf extract possessed an efficacy similar to that of $\beta$-glucan (Ecept the effect on weight gain). Furthermore, a mixture of $\beta$-glucan and mulberry leaf extract showed synergism in improvement of insulin sensitivity ${ }^{(36)}$.

The effect on food intake and weight of flavonoid standardized extract of Morus alba were evaluated in diet-induced obesity in the mice. The extract significantly and dose-dependently reduced the food intake in acute and prolongedtreatment. The extract $(250 \mathrm{mg} / \mathrm{kg}$ ) decreased food intake by $58.6 \%$ and $44.8 \%$ and at a dose of $500 \mathrm{mg} / \mathrm{kg}$ decreased food intake by $50.1 \%$ and $44.3 \%$ at 1 and $2 \mathrm{~h}$ after extract treatment. The high Morus root-bark extract dosecaused 16.5 and $22.5 \%$ loss in body weightat baseline and week 7 , respectively, in obese mice with markeddecrease in visceral fat deposit and biochemical markers ${ }^{(37)}$.

JS-MP-1, a polysaccharideidentified in Morus alba significantly decreased 3T3-L1 pre-adipocyte cells viability, reduced the ratio of the expression level of Bcl-2/Bax which induceddysfunction of mitochondria and preadipocyte cells apoptosis, and stimulated the cleavage of caspases 3 and 9 and poly polymerase. The apoptotic death appeared to be mediated by ERK and p38 signallingstimulation, which indicated that the polysaccharide was able to decrease the adipose tissue mass and the fat cells number via inhibition of proliferation of preadipocyte ${ }^{(38)}$.

The anti-adipogenic and antioxidant effects of Nelumbonucifera Morus alba and Raphanussativus mixture were studied. The mixturedecreasedbody, adipose tissueand liver in high-fat diet. It decreased the glucose and lipid profile elevated by high fat diet. Blood glucose and seruminsulin growth factor-1, leptin and non-esterified fatty acid, were significantly declined, while, serum adiponectin was increased significantly ${ }^{(39)}$.

When the 3T3-L1 cells treated byMorus albaethanolic extracts at $100 \mathrm{microg} / \mathrm{ml}$, the adipocyte differentiation was decreased by $18.6 \%$. It decreasedC/EBPalpha expression and suppressed mRNA of PPARgamma in 3T3-L1 cells. A highest antiadipogeniceffect on 3T3-L1 cells was induced by ethyl acetate fraction. At a concentration of 100 microg/ml, the fraction decreased lipid accumulated intracellularlly by $38.5 \%$. Protocatechulicacid which identified in the fraction, at a concentration of 100 microM, inhibited the accumulation of lipid by $44.8 \%$, therefore the inhibition of lipid accumulation induced by the ethyl acetate fraction could be attributed to protocatechulic acid ${ }^{(40)}$.

The pharmacological activity of UP601 (a mixture of Morus alba, Yerba mate and Magnolia officinalisextracts), was studied on changing of obesity-related parameters and biochemical markers in obesity induced in mice by high fructose (HFF). UP601 at a dose of $250 \mathrm{mcg} / \mathrm{ml}$, induced a 1.8-times increase in lipolysis. UP601 decreased body weight by $9.1,19.6$ and $25.6 \%$ at doses of $300 \mathrm{mg}, 450 \mathrm{mg}$ and $600 \mathrm{mg} / \mathrm{kg}$ for 7 weeks in rats. The same doses caused reduction in the total cholesterol 9.1, 16.9 and 18.6\%; in triglycerides 45.0, 55.0, 63.6\%; in LDL 34.8, 37.1 and $41.6 \%$; and in serum glucose 3.2, 21.6 and $33.7 \%$, respectively. UP601 also caused $31.6 \%$ reduction in the body fat distribution and up to $89.1 \%$ decrease in the mesenteric fat ${ }^{(41)}$.

UP601 (orally, $1.3 \mathrm{~g} / \mathrm{kg} /$ day, for 7 weeks) was also studiedfor its appetite suppression and management of metabolic disorders in mice models. It caused markeddecreases in food intake 81.8, $75.3,43.9$, and $30.9 \%$ at $2,4,6$, and 24 hours. Furthermore, it decreased body weight gain $21.5 \%$ VS $8.2 \%$, at 7 weeks compared with untreated high fat diet-mice, decreased calorie intake $40.5 \%$ at the first week, reduced insulin and leptin by $75.9 \%$ and 
$46.8 \%$, respectively, increased ghrelin level 4.2 times, and significantly decreased cholesterol and LDL. Mice treated by UP601 also showed less body fat, less mesenteric fat pad with an improvement of nonalcoholic steatohepatitis scores ${ }^{(42)}$.

The acute, subacute and chronic toxicological studies in mice and rats showed that Morus alba was a safe remedy with high therapeutic index ${ }^{(7,43-49)}$.

\section{Conclusion}

Morusalbapossessedmany therapeutic effects. The current review discuss its hypolipidemic and antiobesity effect. Morusalbacaused appetite suppression and exerted hypolipidemic and antiobesity effect by many mechanisms. Furthermore the toxicological studies revealed that Morusalbais an edible and very save remedy. It is a promising medical therapy with wide range of pharmacological effects.

\section{Ethics approval and consent to participate}

The work is a review, the authors didn't perform experimental and clinical work.

\section{Consent for publication}

The manuscript didn't contain any individual person's data.

\section{Competing interests}

The author confirm that this paper's content has no conflict of interests.

\section{Funding}

The author received no fund from any source.

\section{Author's contributions}

Both authors drafted the and approved the manuscript

\section{References}

1. Blüher, M. Obesity: global epidemiology and pathogenesis. Nat RevEndocrinol2019; 15: 288298.

2. Warrier PK, Nambiar VPK and Ramankutty C. Morusalba Linn in, Indian Medicinal Plants. Orient Longman Ltd., Vol 4, $1^{\text {st }}$ ed. Hyderabad 1997: 6567.

3. Yamatake $\mathrm{Y}$, Shibata $\mathrm{M}$ and Nagai $\mathrm{M}$. Pharmacological studies on root bark of mulberry tree (MorusalbaL.). Jpn J Pharmacol 1976; 26: 461-469.

4. Chen F, Nakashima Nand Kimura M. Hypoglycemic activity and mechanism of extracts from mulberry leaves; and cortex mori radices in streptozotocininduced diabetic mice. YakugakuZasshi 1995; 115: 476-482.

5. Chevalier A. The encyclopedia of medicinal plants. New York: DK Publishing, 1996: 235.

6. Katsube T, Imawaka N, Kawano Y, Yamazaki Y, Shiwaku K and Yamane Y. Antioxidant flavanol glycosides in mulberry (Morusalba) leaves isolated based on LDL antioxidant activity. Food Chem 2006;97: 25-31.

7. Aditya Rao S, Ramesh C, Padmashali B and Jamuna K. Evaluation of antiinflammatory and analgesic activity in three Morusspecies. Research J Pharmaceut, Biol and ChemSci 2013;4:822-830.

8. Nomura T, Fukai T, Hano Y, Nemato K, Terada $\mathrm{S}$ and Kuramochi T. Constituents of cultivated Mulberry tree. PlantaMedica 1983;47:151-156.

9. Kusano G, Orihara S, Tsukamato D, et al. Five new nortropane alkaloids and six new amino acids from the fruit of Morusalbs growing in Turkey. Chem Pharm Bull 2002;50:185-192.

10. Chen C, Liu L, Yang M and Wang C. Mulberry extract inhibits the development of atherosclerosis in cholesterol fed rabbits. Food Chemistry 2005;91:601-607.

11. Imran $\mathbf{M}$, Khan $\mathrm{H}$, Shah $\mathrm{M}$, Khan $\mathrm{R}$ and Khan F. Chemical composition and antioxidant activity of certain Morusspecies. Journal of Zhejiang University Science B- Biomedicine \& 
Biotechnology 2010;11(12): 973-980.

12. Sánchez-Salcedo EM, Mena P, Martínez JJ and Hernández F. Phytochemical evaluation of white (Morus alba L.) and black (MorusnigraL.) mulberry fruits: A starting point for the assessment of their beneficial properties. J Function Foods 2015; 12: 399-408.

13. Yang $X$, and Zheng $H$. Hypolipidemic and antioxidant effects of mulberry (Morusalba) fruit in hyperlipidaemia rats. Food ChemToxl 2010;48:2374-2379.

14. Bae S H and Suh H J. Antioxidant activities of five different mulberry cultivars in Korea. LWT Food Science and Technology 2007; 40(5): 955-962.

15. Chen PN, Chu SC, Chiang CL and Hsieh YS. Mulberry anthocyanins, cyanidin 3-rutinoside and cyanidin 3-glucoside, exhibited an inhibitory effect on the migration and invasion of a human lung cancer cell line. Cancer Lett 2006;235:248-259.

16. Du Q, and $\mathrm{Xu} \mathrm{Y}$. Composition of anthocyanins in mulberry and their antioxidant activity. J Food Compos Anal 2008;21:390-395.

17. Kwon OC, Ju WT, Kim HB, Sung GB and Kim YS.UPLC-DAD-QTOF/MS analysis of flavonoids from 12 varieties of Korean mulberry fruit. Hindawi Journal of Food Quality 2019, https://doi. org/10.1155/2019/1528917

18. Memon A, Memon N, Bhanger M and Pitafi A. Phenolic acids profiling and antioxidant potential of mulberry (Moruslaevigata W., Morusnigra L., and Morus alba L.) leaves and fruits grown in Pakistan. Pol Journal Food Nutrition Science 2010;60:25-32.

19. Natic' M, Dabic' D, Fotiric' M, Ognjanov V, Ljubojevic' $M$ and Tešic' ŽL. Analysis and characterisation of phytochemicals in mulberry (Morusalba L.) fruits grown in Vojvodina, North Serbia. Food Chem 2015;171:128-136.

20. El-Beshbishy H, Singab A,Sinkkonen $J$ and Pihlaja K. Hypolipidemic and antioxidant effects of MorusalbaL. (Egyptian mulberry) root bark fractions supplementation in cholesterol-fed rats.
Life Sci 2006;78:2724-2733.

21. Wilson RD and Islam MS. Effects of white mulberry (Morus alba) leaf tea investigated in a type 2 diabetes model of rats. Acta Pol Pharm 2015; 72(1): 153-160.

22. Ann JY, and Lim Y. Mulberry leaves (Morusalba L.) ameliorate obesity-induced hepatic lipogenesis, fibrosis, and oxidative stress in high fat diet-fed mice. Genes Nutr 2015;10:1-13.

23. Kobayashi Y, Miyazawa M, Kamei A and Abe K. Effects of Morusalba. (mulberry) leaf extract in hypercholesterolemic mice on suppression of cholesterol synthesis. JournalPharmacognocNatur Prod 2015; 2:1-9.

24. Chang Y, Yang M, Chen S and Wang C. Mulberry leaf polyphenol extract improves obesity by inducing adipocyte apoptosis and inhibiting preadipocyte differentiation and hepatic lipogenesis. J Function Foods 2016;21:249-262.

25. Tond SB, Fallah S, Salemi $Z$ and Seifi $M$. Influence of mulberry leaf extract on serum adiponectin, visfatin and lipid profile levels in type 2 diabetic rats. Brazilian Archives of Biology and Technology2016;53:1-8.

26. Zeni AB and Dall'Molin M. Hypotriglyceridemic effect of MorusalbaL., Moraceae, leaves in hyperlipidemic rats. Brazilian Journal of Pharmacognosy 2010; 20(1): 130-133.

27. Metwally FM, Rashad $\mathrm{H}$ and Mahmoud AA. Morus alba L. Diminishes visceral adiposity, insulin resistance, behavioral alterations via regulation of gene expression of leptin, resistin and adiponectin in rats fed a high-cholesterol diet. PhysiolBehav 2019; 201:1-11.

28. Jo SP, Kim JK and Lim YH. Antihyperlipidemic effects of stilbenoids isolated from Morus alba in rats fed a high-cholesterol diet.Food ChemToxicol 2014; 65: 213-218.

29. Tsuduki T, Nakamura Y, Nakagawa K, Kimura $\mathrm{T}$, Miyazawa T. Intake of 1-deoxynojirimycin suppresses lipid accumulation through activation of 
the beta-oxidation system in rat liver. JournalAgricul Food Chemist 2009; 57:11024-11029.

30. Assiri AMA, El-Beeh ME, Amin AH and Ramadan MF. Ameliorative impact of Morus alba leaves' aqueous extract against embryonic ophthalmic tissue malformation in streptozotocin-induced diabetic rats.Biomed Pharmacother 2017; 95: 1072-1081.

31. Sun X, Yamasaki M, and Shiwaku K. Effects of quercetin derivatives from mulberry leaves: improved gene expression related hepatic lipid and glucose metabolism in short-term high-fat fed mice. Nutrition ResearchPract 2015; 9:137-143.

32. Mahmoud MY. Natural antioxidants effect of mulberry fruits (Morusnigra andMorusalbaL.) on lipids profile and oxidative stress in hypercholestrolemic rats. Pakistan Journal of Nutrition 2013; 12(7): 665-672.

33. Lee M, Kim J, Park J, Kim H, Choi Y, Kim K, Song $\mathrm{H}$ and Hwang D. Anti-obesity effect in high-fatdiet-induced obese C57BL/6 mice: Study of a novel extract from mulberry (Morus alba) leaves fermented with Cordycepsmilitaris.ExpTher Med 2019; 17(3): 2185-2193.

34. Yoon M and Kim MY. The anti-angiogenic herbal composition $\mathrm{Ob}-\mathrm{X}$ from Morus alba, Melissa officinalis, and Artemisia capillaris regulates obesity in genetically obese ob/ob mice. Pharm Biol 2011;49:614-619.

35. Ann JY, Eo H, and Lim Y. Mulberry leaves (Morusalba L.) ameliorate obesity-induced hepatic lipogenesis, fibrosis, and oxidative stress in highfat diet-fed mice. Genes Nutr 2015;10:46.

36. Xu J, Wang X, Cao K, Dong Z, Feng Z and Liu J. Combination of $\beta$-glucan and Morus alba L. Leaf extract promotes metabolic benefits in mice fed a high-fat diet.Nutrients 2017;9(10):doi:10.3390/ nu9101110.

37. Yimam M, Jiao P, Hong M, Brownell L, Lee YC, Kim HJ, Nam JB, Kim MR and Jia Q. Morus alba, a medicinal plant for appetite suppression and weight
loss.J Med Food 2019;22:741-751.

38. Choi JW, Synytsya A, Capek P, Bleha R, Pohl R and Park YI. Structural analysis and anti-obesity effect of a pectic polysaccharide isolated from Korean mulberry fruit Oddi (Morus alba L.). CarbohydrPolym 2016;146: 187-196.

39. Sim W, Choi S, Cho B, Choi S, Han X, Cho H, Kim S, Lee B, Kang I, Cho J and Lee O. Antiobesity effect of extract from Nelumbonucifera, Morus alba, and Raphanussativus mixture in 3T3-L1 adipocytes and C57BL/6J obese mice. Foods 2019;8(5):E170.

40. Park H/, Shim S and Kim G. Inhibitory effects of ethyl acetate-soluble fraction from Morus alba on lipid accumulation in 3T3-L1 cells.Natural Product Communications 2013;8(11):1579-1582.

41. Yimam M, Jiao P, Brownell L, Lee Y, Hyun E, Kim H, Nam J, Kim M and Jia Q. UP601, a standardized botanical composition of Morus alba, Yerba mate and Magnolia officinalis for weight loss.BMC Complement Alternative Medicine 2017;17(1):114.

42. Yimam M, Jiao P, Brownell L, Lee Y, Hyun E, Kim H, Kim T, Nam J, Kim M and Jia Q. Appetite suppression and antiobesity effect of a botanical composition composed of Morus alba, Yerba mate, and Magnoliaofficinalis. Journal ofObesity 2016:4670818.

43. Marx T, Glavits R, Endres J, Palmer P, Clewell A, Murbach T, Hirka G and Pasics I. A twenty days day repeated dose toxicologic study of an aqueous extract of Morus alba. InternationalJournal of Toxicology 2016;35:683-691.

44. Oliveira A, Mesquita M, Silva G, Lima E, Medeiros P, Paiva P, Souza I, and Napoleão T. Evaluation of toxicity and antimicrobial activity of an ethanol extract from leaves of Morus alba (Moraceae). Evidence Based Complementary and Alternative Medicine 2015:513978.

45. Yimam M, Jiao P, Brownell L, Hyun-Jin Kim, Lee YC and Jia Q. Repeated dose twenty eight days oral 
toxicity study of a botanical composition of Morus alba and Acacia catechu in rats. Regulatory Toxicology and Pharmacology 2018;94:115-123.

46. Food and Agric. Org. Proceedings of an Electronic Conference. May - August 2000. Animal Production and Health Paper 147. VialedelleTerme di Caracalla, Rome, Italy: FAO, 2002.

47. Prasad P, Redy D, Reddy M and Reddy G. Effect of feeding mulberry (Morus alba) hay in the rations to pregnant ewes. Indian Journal of Animal Nutrition 1995;12:109-111.
48. Prasad $\mathrm{P}$ and Reddy M. Nutritive values of mulberry (Morusalba) leaves in goats and sheep. Indian Journal Animal Nutrition 1991;8:295-296.

49. Kandylis K, Hadjige I and Hariznis P. The nutritive values of mulberry leaves (Morusalba) as a feed supplement for sheep. Tropical Animal Healthand Production 2009;41:17-24.

ORIGINAL ARTICLE 